\title{
PENGARUH MEDIA ICT BERBASIS FOR VBA EXCEL TERHADAP SELF CONFIDENCE MATEMATIS SISWA SD PADA MATERI BANGUN RUANG
}

\author{
Listya Ambarwati Sholeha ${ }^{1}$, Desi Novianti ${ }^{2}$, Siti Chotimah $^{3}$ \\ 1,2,3 IKIP Siliwangi, Jl. Terusan Jendral Sudirman, Cimahi tengah, Kota Cimahi, Jawa Barat \\ listya922@gmail.com
}

\begin{abstract}
The purpose of this study is to describe the confidence of MI students by using ICT-based media for VBA excel on space building material. The research method used is descriptive qualitative method. The research subjects were 23 students of MI Tazkya class VI. The instrument provided consisted of a student confidence scale questionnaire consisting of 25 definitions and 4 answer choices, namely 1. Strongly Agree (SS), 2. Agree (S), 3. Disagree (TS), 4. Very Disagree (STS ). The self-confidence questionnaire related to superior VBA-based ICT media consists of 5 indicators. The results of the study that showed the confidence of MI Tazkya students by using ICT-based media for superior VBA in the overall building material were classified as good and in accordance with 4 indicators that led to a good proposal for indicators Believe in support well, were they anxious (good), indicators and had drive for achievement (good); indicator Know your strengths and weaknesses (s good). There is one indicator that falls into the criteria, which is the indicator Feel free, and is responsible for its actions (enough). And it can be seen that on average all students are included in both criteria.
\end{abstract}

Keywords: VBA Excel, Self Confidence, Geometry

\begin{abstract}
Abstrak
Tujuan penelitian ini adalah untuk mendeskripsikan kepercayaan diri siswa MI dengan menggunakan media ICT berbasis for VBA excel pada materi bangun ruang. Metode penelitian yang digunakan adalah metode kualitatif deskriptif. Subjek penelitian yang dilakukan yaitu pada 23 siswa MI Tazkya kelas VI. Instrumen yang diberikan berupa angket skala kepercayaan diri siswa yang terdiri dari 25 pernyataan dan 4 pilihan jawaban yaitu 1. Sangat Setuju (SS), 2.Setuju (S), 3.Tidak Setuju (TS), 4. Sangat Tidak Setuju (STS). Angket kepercayaan diri yang berhubungan dengan media ICT berbasis VBA excel terdiri dari 5 indikator. Hasil penelitian menunjukan bahwa kepercayaan siswa MI Tazkya dengan menggunakan media ICT berbasis for VBA excel pada materi bangun ruang secara keseluruhan tergolong baik dan terdapat 4 indikator yang masuk kriteria baik yaitu untuk indikator Percaya kepada kemampuan sendiri, tidak cemas (baik), indikator Berani mengungkapkan pendapat dan memiliki dorongan untuk berprestasi (baik); indikator Mengenal kelebihan dan kekurangan diri sendiri (s baik ). Terdapat 1 indikator yang masuk kriteria cukup yaitu indikator Merasa bebas, dan bertanggung jawab atas perbuatannya (cukup). Dan dapat dilihat rata-rata persentase keseluruhan semua siswa termasuk kedalam kriteria baik.
\end{abstract}

Kata kunci: VBA Excel, Self Confidence, Bangun ruang

Dalam upaya meningkatkan kualitas dan mengembangkan potensi, serta mengembangkan ilmu pengetahuan dan teknologi, setiap individu diwajibkan mengenyam pendidikan, salah satu budang studi yang mendukungnya adalah matematika (Chotimah, at. al, 2019). Matematika merupakan pembelajaran yang masih dianggap sulit oleh para siswa. Padahal, jika kita telaah lebih dalam tentang matematika adalah subjek yang sangat penting dalam kehidupan manusia, karena matematika sangat berperan penting dalam hampir segala aspek baik dalah kehidupan sehari-hari bahkan di masa teknologi dan digital pada sekarang ini (Bernard \& Senjayawati, 2019). Siswa yang masih menganggap matematika adalah pelajaran yang sulit dan menimbulkan kesan dan pengalaman yang negatif pada umumnya akan berdampak buruk, baik untuk motivasi belajar matematikanya maupun prestasi akademik disekolahnya.

Pada era globalisasi ini teknologi sudah berpengaruh dalam segala aspek kehidupan baik dibidang kebudayaan seni, politik, ekonomi bahkan dalam dunia pendidikan. Tuntutan global menuntut 
dunia pendidikan untuk selalu dan senantiasa menyesuaikan perkembangan teknologi terhadap usaha dalam peningkatan mutu pendidikan, terutama penyesuaian penggunaannya bagi dunia pendidikan khususnya dalam proses pembelajaran (Budiman, 2017). Maka melalui teknologi, pembelajaran matematika bisa membuat siswa untuk tertarik dalam pembelajaran. Salah satu teknologi yang dapat di manfaatkan dalam pembelajaran yaitu melalui Game (Bernard, 2015).

Game edukasi berbasis komputer sebagai salah satu media yang efektif digunakan bagi siswa, terutama pada mata pelajaran yang sulit, seperti matematika. Sekalipun telah diketahui secara universal bahwa komputer tidak dapat menggantikan peran guru, namun game berbasis komputer merupakan alat untuk membantu siswa mencapai remediasi (Siregar, 2017). Media yang dapat diterapkan dalam pembelajaran ini yaitu melalui pembelajaran berbasis VBA Excel, karena dalam VBA Excel tak hanya dapat di gunakan dalam mengolah data, namun VBA Excel dapat digunakan untuk pembelajaran kepada siswa dengan tampilan yang lebih menarik (Bernard, 2018). Dengan demikian pembelajaran menggunakan media VBA Excel ini diharapkan dapat meningkatkan kemampuan kepercayaan diri atau self confidence siswa selama pembelajaran.

Menurut Walgio (Purwasih, 2015) salah satu cara untuk menumbuhkan self confidence adalah dengan melatih setiap individu untuk dapat mengemukakan pendapat kepada pihak lain melalui interaksi sosial, dilatih berfikir mandiri dan diberi suasana yang aman sehingga individu tidak takut berbuat kesalahan. Menurut TIMSS (Purwasih, 2015) menyatakan bahwa self confidence siswa Indonesia masih rendah yaitu masih dibawah persentase 30\%. Dengan demikian untuk menumbuhkan kemampuan self confidence siswa yaitu dengan kerja kelompok. Sehingga pembelajaran menggunakan Media ICT Berbasis For VBA Excel dapat berpengaruh bagi kemampuan Self Confidence Matematis Siswa SD pada Materi Bangun Ruang. Berdasarkan permasalahan dan pendapat-pendapat yang telah diungkapkan di atas, peneliti melakukan penelitian dengan judul Pengaruh Penggunaan Media ICT Berbasis For VBA Excel terhadap Self Confidence Matematis Siswa SD pada Materi Bangun Ruang.

\section{METODE}

Jenis penelitian ini adalah penelitian kualitatif desktritif. Penelitian ini bertujuan untuk menganalisis keprcayaan diri belajar siswa SD dengan menggunakan ICT berbasis VBA Excel pada materi Bangun Ruang yang berpedoman pada terpenuhi atau tidaknya indikator-indikator motivasi belajar. Adapun subjek penelitian ini yaitu 23 siswa SD kelas VI di Kabubaten Bandung Barat. Waktu penelitian dilakukan pada akhir semester ganjil tahun ajaran 2019-2020. Pengumpulan data dalam penelitian menggunakan instrumen angket skala kepercayaan diri. Instrumen digunakan sebagai upaya untuk memperoleh data primer dalam kepercayaan diri siswa SD kelas VI. Adapun cangkupan materi yang disampaikan peneliti sebelum siswa memberikan respon instrument angket peneliti menerangkan materi bangun ruang menggunakan media ICT berbasis VBA Excel. Instrumen yang di gunakan dalam penelitian adalah angket skala kepercayaan diri yang terdiri dari 25 pernyataan dan 5 indikator yang berhubungan dengan media ICT berbasis VBA Excel dan 4 pilihan jawaban. Pemberian skor hasil tes 
siswa di dasarkan pada indikator yang akan dicapai. Selanjutnya skor per indikator dan skor keseluruhan siswa dikonversi dalambentuk nilai skala(1-100) serta menafsirkan data sesuai kriteria pemahaman berdasarkan Arikunto. Data dikatagorikan dengan menggunakan batasan yang ditemukan oleh Arikunto (dalam Romlah 2019), batasan tersebut tercantum pada Tabel 1 berikut ini:

Tabel 1.

Kriteria Data

\begin{tabular}{|c|c|}
\hline Persentase & Kriteria \\
\hline $81-100$ & Baik sekali \\
\hline $61-80$ & Baik \\
\hline $41-60$ & Cukup \\
\hline $21-40$ & Kurang \\
\hline $0-20$ & Kurang Sekali \\
\hline
\end{tabular}

HASIL

Angket kepercayaan diri yang terdiri dari 5 indikator beserta 25 skala pernyataan. Angket tersebut terdapat empat pilihan jawaban, yaitu sangat setuju (SS), setuju (S), tidak setuju (TS), dan sangat tidaksetuju (TST).Angket yang diberikan berupa angket tertutup kepada 23 siswa. Pengolahan dan analisis data angket dilakukan melalui menentukan presentase jawaban siswa.

\section{Tabel 2. Presentase Hasil Data Penelitian}

\begin{tabular}{|c|c|c|c|c|c|c|}
\hline \multirow[b]{2}{*}{ No. } & \multirow{2}{*}{ Indikator } & \multirow{2}{*}{ Pernyataan } & \multicolumn{4}{|c|}{ Respons } \\
\hline & & & SS & $\mathbf{S}$ & TS & STS \\
\hline A. 2 & $\begin{array}{ll}\text { Percaya } & \text { kepada } \\
\text { kemampuan } & \text { sendiri, } \\
\text { tidak cemas. } & \\
\end{array}$ & $\begin{array}{l}\text { Saya merasa takut untuk menjawab bila } \\
\text { guru bertanya tentang materi bangun ruang }\end{array}$ & 4,34 & 13,04 & 72,72 & 13,63 \\
\hline B. 3 & $\begin{array}{l}\text { Merasa bebas, dan } \\
\text { bertanggung jawab } \\
\text { atas perbuatannya }\end{array}$ & $\begin{array}{l}\text { Saya berusaha keras mengerjakan tugas } \\
\text { materi bangun ruang yang sulit }\end{array}$ & 56,52 & 30,43 & 8,69 & 4,34 \\
\hline C. 2 & $\begin{array}{lr}\text { Bertindak } & \text { mandiri } \\
\text { dalam } & \text { mengambil } \\
\text { keputusan } & \end{array}$ & $\begin{array}{l}\text { Saya merasa tidak mampu ketika ada tugas } \\
\text { menyelesaikan soal pada materi bangun } \\
\text { ruang }\end{array}$ & 8,69 & 8,69 & 65,21 & 17,39 \\
\hline D. 4 & $\begin{array}{l}\text { Berani } \\
\text { mengungkapkan } \\
\text { pendapat dan } \\
\text { memiliki dorongan } \\
\text { untuk berprestasi }\end{array}$ & $\begin{array}{l}\text { Saya berpendapat jika guru dalam } \\
\text { menerangkan materi bangun ruang dengan } \\
\text { menggunakan media VBA Excel akan lebih } \\
\text { sulit memahaminya dan menghambat } \\
\text { mencapai nilai yang baik }\end{array}$ & 13,04 & 8,69 & 60,86 & 17,39 \\
\hline E. 1 & $\begin{array}{l}\text { Mengenal kelebihan } \\
\text { dan kekurangan diri } \\
\text { sendiri }\end{array}$ & $\begin{array}{l}\text { Saya sadar sudah melakukan kesalahan } \\
\text { dalam ulangan matematika minggu lalu }\end{array}$ & 60,86 & 26,08 & 8,69 & 4,34 \\
\hline
\end{tabular}

Berdasarkan tabel 2 hasil pengolahan data di atas akan dibahas mengenai pencapaian penggunaan media ICT berbasis for VBA Ecxel terhadap kepercayaan diri siswa SD. Dalam pernyataan 
diatas ada 5 pernyataan dan 5 indikator yang berkaitan dengan media ICT berbasis for VBA dan yang memiliki persentase tertinggi diantara pernyataan lainnya.

Pada indikator pertama "Percaya kepada kemampuan sendiri, tidak cemas." terdapat pada pernyataan nomor 2 yang bernilai negatif, siswa paling banyak memberikan respon tidak setuju dengan persentase sebesar 72,72 \%. Pernyataan itu "Saya merasa takut untuk menjawab bila guru bertanya tentang materi bangun ruang" jadi dapat disimpulkan bahwa siswa dapat memahami materi bangun ruang dengan baik dan tidak merasa takut ketika guru memberikan permasalahan dan berani untuk menjawab permaslahan tersebut. (Baik).

Pada indikator kedua yaitu "Merasa bebas, dan bertanggung jawab atas perbuatannya" yang terdapat pada pernyataan nomor 3 yang bernilai positif, siswa paling banyak memberikan respon sangat setuju dengan persentase sebesar $56.85 \%$. Pernyataan itu "Saya berusaha keras mengerjakan tugas materi bangun ruang yang sulit" jadi dapat disimpulkan bahwa siswa tidak pantang menyerah ketika Guru memberikan permasalahan matematika bangun ruang. Siswa tetap mengerjakan permasalahan bangun ruang yang sulit hingga mereka mendapatkan hasil yang benar. (Cukup).

Pada indikator ketiga yaitu "Bertindak mandiri dalam mengambil keputusan" yang terdapat pada pernyataan nomor 2 yang bernilai negatif, siswa paling banyak memberikan respon tidak setuju dengan persentase sebesar 65,21\%. Pernyataan itu "Saya merasa tidak mampu ketika ada tugas menyelesaikan soal pada materi bangun ruang" jadi dapat disimpulkan bahwa siswa mengaku bisa menyelesaikan tugas materi bangun ruang dengan baik (Baik).

Pada indikator keempat yaitu "Berani mengungkapkan pendapat dan memiliki dorongan untuk berprestasi" yang terdapat pada pernyataan nomor 4 yang bernilai negatif, siswa paling banyak memberikan respon tidak setuju dengan persentase sebesar 60,86 \%. Pernyataan itu "Saya berpendapat jika guru dalam menerangkan materi bangun ruang dengan menggunakan media VBA Excel akan lebih sulit memahaminya dan menghambat mencapai nilai yang baik" jadi disimpulkan bahwa siswa dapat memahami dengan baik bila Guru menerangkan materi bangun ruang menggunakan media VBA Excel dan sangat membantu siswa untuk mencapai nilai yang baik. (Baik).

Pada indikator terakhir yaitu indikator kelima "Mengenal kelebihan dan kekurangan diri sendiri” yang terdapat pada pernyataan nomor 1 yang bernilai positif, siswa paling banyak memberikan respon sangat setuju dengan persentase sebesar 60,86 \%. Pernyataan itu "Saya sadar sudah melakukan kesalahan dalam ulangan matematika minggu lalu" jadi disimpulkan bahwa siswa kurang maskimal dalam mempersiapkan ulangan matematika materi bangun ruang dengan baik sehingga mendapatkan nilai yang kurang bagus, namun para siswa menyadari bahwa tindakan tersebut tidak baik bila diulang kembali di ulangan matematika selanjutnya. (Baik).

Berdasarkan penjelasan dari kelima pernyataan dan kelima indikator di atas dapat disimpulkan bahwa penggunaan media ICT berbasis for VBA Ecxel dalam pembelajaran matematika dapat mempengaruhi kepercayaan diri siswa lebih meningkat. Hal ini pun bersesuaian dengan penelitian yang telah dilakukan oleh Pertiwi (2018) Kepercayaan diri sangat penting dimiliki siswa karena akan 
menjadikan siswa lebih bertanggung jawab dalam bertindak, utamanya dalam belajar, optimis dalam menyelesaikan soal-soal yang menantang, bahkan dapat mempengaruhi temannya untuk memiliki pandangan positif terhadap matematika. Dari hasil penelitian Rizki (2015) bahan ajar berbasis ICT ini sangat baik untuk digunakan dalam proses pembelajaran. Lebih lanjut dari hasil analisis data dapat disimpulkan bahwa ada pengaruh yang sangat signifikan pada motivasi belajar siswa dan penggunaan bahan ajar berbasis ICT terhadap hasil belajar. Bernard \& Senjayawati(2019) juga menyatakan pembelajaran berbasis ICT VBA Excel lebih menarik dan menambah kepercayaan diri siswa dalam belajar matematika dan meningkatkan hasil belajar siswa (Bernard, 2019). Sedangkan hasil penelitian dari Chotimah, Bernard, Wulandari, (2018) bahwa media pembelajaran VBA dapat meningkatkan kemampuan pemahaman matematik Siswa.

\section{KESIMPULAN}

Berdasarkan hasil dan pembahasan penelitian yang telah disajikan di atas, maka dapat disimpulkan bahwa hasil rata-rata skor dari salah satu pernyataan dari setiap indikator, siswa termasuk kedalam kriteria baik yaitu 63,3\%. kepercayaan siswa MI Tazkya dengan menggunakan media ICT berbasis for VBA excel pada materi bangun ruang secara keseluruhan tergolong baik dan terdapat 4 indikator yang masuk kriteria baik yaitu untuk indikator Percaya kepada kemampuan sendiri, tidak cemas (baik), indikator Berani mengungkapkan pendapat dan memiliki dorongan untuk berprestasi (baik); indikator Mengenal kelebihan dan kekurangan diri sendiri (s baik ). Terdapat 1 indikator yang masuk kriteria cukup yaitu indikator Merasa bebas, dan bertanggung jawab atas perbuatannya (cukup). Dan dapat dilihat rata-rata persentase keseluruhan semua siswa termasuk kedalam kriteria baik.

\section{DAFTAR PUSTAKA}

Bernard, M. (2015). Meningkatkan kemampuan komunikasi dan penalaran serta disposisi matematik siswa SMK dengan pendekatan kontekstual melalui game adobe flash cs 4.0. Infinity Journal, 4(2), 197-222.

Bernard, M., \& Senjayawati, E. (2019). Developing the Students' Ability in Understanding Mathematics and Self-confidence with VBA for Excel. JRAMathEdu (Journal of Research and Advances in Mathematics Education), 1(1), 45-56.

Bernard, M., \& Chotimah, S. (2018, September). Improve student mathematical reasoning ability with open-ended approach using VBA for powerpoint. In AIP Conference Proceedings (Vol. 2014, No. 1, p. 020013). AIP Publishing.

Bernard, M., Sunaryo, A., Tusdia, H., Hendriani, E., Suhayi, A., Parida, M., ... \& Rolina, R. (2019, October). Enhance Learning Independence and Self Ability of Exceptional Children Through Developing Learning Media VBA for Excel Games. In Journal of Physics: Conference Series (Vol. 1315, No. 1, p. 012037). IOP Publishing. 
Bernard, M., Sumarna, A., Rolina, R., \& Akbar, P. (2019, October). Development of high school student work sheets using VBA for microsoft word trigonometry materials. In Journal of Physics: Conference Series (Vol. 1315, No. 1, p. 012031). IOP Publishing.

Bernard, M., \& Senjayawati, E. (2019). Meningkatkan Kemampuan Koneksi Matematik Siswa SMP dengan Menggunakan Pendekatan Metaphorical Thinking Berbantuan Software Geogebra. Jurnal Mercumatika: Jurnal Penelitian Matematika dan Pendidikan Matematika, 3(2), 79-87.

Budiman, H. (2017). Peran Teknologi Informasi dan Komunikasi dalam Pendidikan. Jurnal Pendidikan Islam, 8(I), 31-43.

Chotimah, S., Bernard, M., \& Wulandari, S. M. (2018, January). Contextual approach using VBA learning media to improve students' mathematical displacement and disposition ability. In Journal of Physics: Conference Series (Vol. 948, No. 1, p. 012025). IOP Publishing.

Chotimah, S., Ramdhani, F. A., Bernard, M., \& Akbar, P. (2019). Pengaruh Pendekatan Model-Eliciting Activities Terhadap Kemampuan Berpikir Kritis Matematik Siswa Smp Negeri Di Kota Cimahi. Journal on Education, 1(2), 68-77.

Purwasih, R. (2015). Peningkatan Kemampuan Pemahaman Matematis dan Self Confidence Siswa MTs di Kota Cimahi melalui Model Pembelajaran Inkuiri Terbimbing. Jurnal Ilmiah STKIP Siliwangi Bandung, 9, 16-25.

Pertiwi, C. M., Jayanti, R. A., \& Afrilianto, M. (2018). ASOSIASI ANTARA KEMAMPUAN GENERALISASI MATEMATIK DENGAN SELF-CONCEPT SISWA SMP YANG MENGGUNAKAN STRATEGI PEMBELAJARAN BERBASIS VBA MICROSOFT EXCEL. JPMI (Jurnal Pembelajaran Matematika Inovatif), 1(3), 371-382.

Rizki \& Widaniati. (2015). Efektifitas Bahan Ajar dan Media Berbasis ICT Pada Materi Persamaan dan Fungsi Kuadrat. AKSIOMA: Jurnal Progran Studi Pendidikan Matematika, 4(2)

Romlah, S., Nugraha, N., \& Setiawan, W. (2019). Analisis Motivasi Belajar Siswa SD Albarokah 448 Bandung dengan Menggunakan Media ICT Berbasis For VBA Excel Pada Materi Garis Bilangan. Jurnal Cendekia: Jurnal Pendidikan Matematika, 3(1), 220-226.

Siregar, N. R. (2017). Persepsi Siswa Pada Pelajaran Matematika: Studi Pendahuluan Pada Siswa yang Menyenangi Game. Prosiding Temu Ilmiah X Ikatan Psikologi Perkembangan Indonesia, 224232. Retrieved from https://www.google.co.id/search?q=Persepsi+siswa+pada+pelajaran+matematika\%253A+studi+ pendahuluan+pada+siswa+yang+menyenangi+game+Nani+Restati+Siregar1+1Mahasiswa+Prog ram+Doktor+Psikologi+Universitas+Gadjah+Mada\&oq=Persepsi+siswa+pada+pelajaran+mate matika 